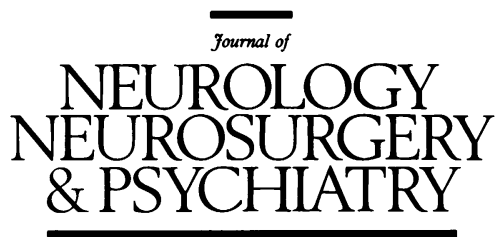

\title{
Editorial
}

\section{On guidelines for the management of the severe head injury}

The charitable American Trauma Brain Foundation has assembled and financed an expert task force to suggest guidelines for the management of patients with severe head injury (Glasgow coma score of 3-8 on presentation). They have addressed the concern that the clinical practise for these patients is diverse. ${ }^{1}$ The task force selected 14 topics considered central to optimal care of head injury, and used a systematic process of review to gather the available evidence. After critical analysis of selected publications, recommendations were put forward, and the degree of clinical certainty which accompanied the evidence for each topic was emphasised. Successive versions of the guidelines have been reported to the American Association of Neurological Surgeons and other North American medical societies, inviting detailed criticism. The suggested guidelines were also presented to a consortium of European neurosurgeons with expertise in neurotrauma for peer review. As new evidence becomes available, they anticipate that the recommendations will be updated in later editions.

The process of evaluating the scientific evidence was largely restricted to information obtained by means of Medline. Publications dating back to 1966 were searched using targeted keywords. References obtained in this way were assessed for suitability of design, content and relevance. A high proportion of these were subsequently rejected. Of those publications deemed suitable, a summary and a conclusion were provided under each topic heading. The process adopted would have identified most of the important studies, but a significant wealth of information may have been missed from non-English cultures, such as that in the Japanese literature. An extended systematic review of the literature, such as that recommended by the Cochrane Collaboration, ${ }^{2}$ was not undertaken. Although the international experience of the task force will compensate for this, the exclusion of such data may affect the acceptance of the guidelines in some countries. However, now that the framework for update has been established, it is envisaged that future studies from diverse international sources can be reviewed and included with relative ease.

The problems encountered in providing evidence for clinical guidelines in severe head injury are well known to those managing these patients. A detailed account of these difficulties is comprehensively stated by the authors in the introduction. The process of review and critical analysis (specifically avoiding personal opinion) led the task force to consider the available evidence of insufficient clinical certainty to provide "standards" for 11 of the 14 topics reviewed (table). This is a distinctive feature of the document which recurrently highlights the lack of quality data available for key issues in management of head injury. Thus class $I$ data (prospective randomised controlled trials) necessary for setting standards is generally not available. Rather, "guidelines" with a moderate degree of clinical certainty from class II data (high quality prospective and retrospective data), and "options" based on information with unclear clinical certainty (class III data), are offered.

Centralisation of effort into recognised head injury units which have expertise in the intensive care management of these patients is central to the task force's conclusions. Guidelines are only of use if they can be implemented in a competent and reliable way by specialist personnel who have an interest in treating this difficult condition. Receiving suitably resuscitated head injured patients in a timely fashion is dependent on highly organised trauma services, and access to 24 hour advanced trauma life support (ATLS) evaluation. Realistically, this can only be implemented within designated trauma units with on site neurosurgical support, and the supporting evidence has encouraged the task force to promote the provision for trauma centres as a guideline.

The task force have been confident in providing standards for three topics. Carefully conducted randomised trials show that steroid therapy is of no efficacy and is not recommended (topic 11, table). Although anticonvulsants reduce the incidence of early post-traumatic seizures, they do not seem to reduce the occurrence of late post-traumatic seizures (topic 14; table 1), hence long term prophylactic treatment is not recommended. Thirdly, the data detailing the case against prolonged hyperventilation in the absence of raised intracranial pressure has been considered sufficient to provide a standard (topic 8, table). Prolonged hyperventilation causing profound cerebral vasoconstriction and secondary cerebral ischaemia should be avoided. However, acknowledgement is made that controlled hyperventilation can still be used to reduce persistent intracranial hypertension provided cerebral oxygenation is monitored carefully. ${ }^{3}$

The class II evidence for promoting resuscitation to correct hypoxia and hypotension in those with severe head injury is overwhelming. Despite this, the task force considered that they could not issue standards for the precise threshold of arterial blood pressure and blood oxygenation. As there is a universal agreement that a randomised 
Summary of the standards, guidelines, and options on the treatment of the patient with severe head injury offered by the task force for the Brain Trauma Foundation

\begin{tabular}{|c|c|c|c|c|}
\hline Topic & Subject & Standards & Guidelines & Options \\
\hline 1 & Trauma centres & None & $\begin{array}{l}\text { All regions should have an organised } \\
\text { trauma care system }\end{array}$ & $\begin{array}{l}\text { Trauma facilities treating severe head injuries should have } \\
\text { a neurosurgical service, an available trauma surgeon, and } \\
\text { support facilities including CT. Rural hospitals should } \\
\text { have sufficient expertise to carry out an emergency } \\
\text { craniotomy for a space occupying haematoma }\end{array}$ \\
\hline 2 & $\begin{array}{l}\text { Initial resuscitation } \\
\text { of patients } \\
\text { with head injury }\end{array}$ & None & None & $\begin{array}{l}\text { Rapid physiological resuscitation. Sedation and } \\
\text { neuromuscular blockade for safe transfer of patients using } \\
\text { short acting agents. Mannitol bolus given } \\
\text { in cases of neurological deterioration }\end{array}$ \\
\hline 3 & $\begin{array}{l}\text { Resuscitation of } \\
\text { blood pressure and } \\
\text { oxygenation }\end{array}$ & None & $\begin{array}{l}\text { Hypotension (systolic } \\
\text { pressure }<90 \mathrm{~mm} \mathrm{Hg} \text { ) and hypoxia } \\
\text { (arterial po } 2<60 \mathrm{~mm} \mathrm{Hg} \text { ) need to be } \\
\text { avoided }\end{array}$ & $\begin{array}{l}\text { Maintain mean arterial pressure above } 90 \mathrm{~mm} \mathrm{Hg} \text { to } \\
\text { maintain cerebral perfusion pressure above } 70 \mathrm{~mm} \mathrm{Hg}\end{array}$ \\
\hline 4 & $\begin{array}{l}\text { Indication for ICP } \\
\text { monitoring }\end{array}$ & None & $\begin{array}{l}\text { Patients with a severe head injury (GCS } \\
3-8 \text { after resuscitation) with abnormal } \\
\text { CT }\end{array}$ & $\begin{array}{l}\text { Patients with a moderate head injury with an abnormal scan. } \\
\text { Those with a severe head injury with a normal scan }\end{array}$ \\
\hline 5 & $\begin{array}{l}\text { ICP treatment } \\
\text { threshold }\end{array}$ & None & $\begin{array}{l}\text { ICP treatment should be instigated at an } \\
\text { upper threshold of } 20-35 \mathrm{~mm} \mathrm{Hg}\end{array}$ & $\begin{array}{l}\text { ICP treatment should be corroborated by clinical } \\
\text { examination and cerebral perfusion data }\end{array}$ \\
\hline 6 & $\begin{array}{l}\text { Recommendations } \\
\text { for ICP monitoring } \\
\text { technology }\end{array}$ & None & None & Intraventricular and intraparenchymal devices are suitable \\
\hline 7 & $\begin{array}{l}\text { Cerebral perfusion } \\
\text { pressure (CPP) }\end{array}$ & None & None & CPP should be maintained above $70 \mathrm{~mm} \mathrm{Hg}$ \\
\hline 8 & $\begin{array}{l}\text { Hyperventilation in } \\
\text { head injury }\end{array}$ & $\begin{array}{l}\text { Avoid prolonged } \\
\text { hyperventilation } \\
\text { (arterial pCO }< \\
25 \mathrm{~mm} \mathrm{Hg})\end{array}$ & $\begin{array}{l}\text { Avoid prophylactic hyperventilation } \\
\text { (arterial } \mathrm{pCO}_{2}<35 \mathrm{~mm} \mathrm{Hg} \text { ) during the } \\
\text { first } 24 \text { hours when cerebral blood flow } \\
\text { is often reduced }\end{array}$ & $\begin{array}{l}\text { Use hyperventilation for brief periods to reduce } \\
\text { acute rises in ICP, or to treat refractory intracranial } \\
\text { hypertension }\end{array}$ \\
\hline 9 & $\begin{array}{l}\text { Mannitol treatment } \\
\text { for raised ICP }\end{array}$ & None & $\begin{array}{l}\text { Intermittent boluses may be more } \\
\text { effective than continuous infusions }\end{array}$ & $\begin{array}{l}\text { Prior to ICP monitoring, mannitol can be used in the } \\
\text { emergency treatment of cerebral herniation. Blood volume } \\
\text { should be maintained by fluid replacement }\end{array}$ \\
\hline 10 & $\begin{array}{l}\text { Use of barbiturates } \\
\text { for controlling raised } \\
\text { ICP }\end{array}$ & None & $\begin{array}{l}\text { Barbiturates can be considered for } \\
\text { treatment of in refractory intracranial } \\
\text { hypertension in potentially salvageable } \\
\text { patients }\end{array}$ & \\
\hline 11 & $\begin{array}{l}\text { Glucocorticoid } \\
\text { therapy }\end{array}$ & $\begin{array}{l}\text { Glucocorticoid } \\
\text { therapy not } \\
\text { recommended }\end{array}$ & None & None \\
\hline 12 & $\begin{array}{l}\text { Critical pathway for } \\
\text { treating established } \\
\text { intracranial } \\
\text { hypertension }\end{array}$ & None & None & Suggested treatment algorithm provided \\
\hline 13 & Nutritional support & None & $\begin{array}{l}\text { Initiate replacement }(100-140 \% \text { of } \\
\text { resting metabolic expenditure) using } \\
\text { parenteral or enteral route by the seventh } \\
\text { day }\end{array}$ & Jejunal feeding preferred \\
\hline 14 & $\begin{array}{l}\text { Prophylactic } \\
\text { anticonvulsants }\end{array}$ & $\begin{array}{l}\text { Prophylactic use } \\
\text { of anticonvulsants } \\
\text { not recommended }\end{array}$ & None & Prophylactic treatment for those at high risk of seizures \\
\hline
\end{tabular}

The 14 selected topics are common to the patient with severe head injury (Glasgow coma score 3-8), but can be applied to lesser grades of head injury under certain circumstances (for example, the patient with moderate head injury with an abnormal CT). ICP $=$ intracranial pressure.

trial to define the lower thresholds for these parameters cannot be carried out due to ethical concerns, the task force may have been obliged to issue a standard that states the importance of avoiding significant hypotension (systolic pressure $<90 \mathrm{~mm} \mathrm{Hg}$ ) and profound hypoxia (arterial $\mathrm{po}^{2}<60 \mathrm{~mm} \mathrm{Hg}$ ) before and after hospital admission irrespective of patient age. ${ }^{45}$ Optimal levels of blood pressure and cerebral perfusion pressure (cerebral perfusion pressure $=$ arterial blood pressure minus intracranial pressure) are not known, and may vary between patients. Randomised trials designed to define optimal thresholds in these variables are currently under way in North American centres. However, maintenance of a cerebral perfusion pressure at $70 \mathrm{~mm} \mathrm{Hg}$ is offered by the task force as an opinion.

Data concerning the benefit of intracranial pressure monitoring was also found to be insufficient to offer it as a standard. The level of raised intracranial pressure at which treatment should be instigated remains a subject of great dispute $^{6}$ and publications on this matter preclude the publication of guidelines. Nevertheless, the task force offers an intracranial pressure threshold of $20-25 \mathrm{~mm} \mathrm{Hg}$ at which point intracranial pressure reducing therapy may be considered. In attempting to achieve this, mannitol administration may be more effective in a bolus form, and barbiturate therapy may be considered for refractory cases. Whichever method is chosen for intracranial pressure control, the preservation of blood pressure is stressed throughout, and the importance of calculating values for cerebral perfusion pressure is emphasised. An optional critical pathway for the treatment of intracranial hypertension has been generated by expert consensus (class III data), and although the algorithm provided gives a basic framework for therapy, the authors fully acknowledge that this may be inappropriate for an individual patient. For example, the administration of mannitol (an agent which increases cerebral blood flow) for treating raised intracranial pressure secondary to hyperaemia is potentially 
harmful. ${ }^{6}$ Adequate cerebral monitoring in each individual case is clearly important in preventing stereotyped guidelines from falling into disrepute. ${ }^{7}$

In summary, the document initiated by the American Trauma Brain Foundation provides a welcomed comprehensive review of modern management of head injury. The systematic and non-bias analytical approach has highlighted the paucity of high quality published data allowing standards to be set. Nevertheless, rather than dismiss the available evidence, the task force has debated the issues and generated guidelines, and in doing so they have provided a basic database which allows for future update. It is not the intention of the participants to standardise care of head injury throughout the world, a difficult task given the great heterogeneity in the geographical, resource related, and pathophysiological variables operating in different head injury units. However, without such standardisation, it is difficult to envisage how multicentre randomised trials can ever achieve sufficient power to prove efficacy for a given therapy.
PETER J KIRKPATRICK MRC Cambridge Centre for Brain Repair and Academic Neurosurgical Unit,

Addenbrooke's Hospital,

PO Box 167, Cambridge CB2 2QQ, UK

Correspondence: Mr P J Kirkpatrick.

1 Ghajar J, Hariri RJ, Narayan RK, et al. Survey of critical care management of comatose, head injured patients in the United States. Crit Care Med 1995;23:560-7.

2 Counsell CE, Fraser H, Sandercock PAG. Archie Cochrane's challenge: can periodically updated reviews of all randomised controlled trials relevant to neurology and neurosurgery be produced? $\mathcal{f}$ Neurol Neurosurg Psychiatry 1994;57:529-33.

3 Sheinberg M, Kanter MJ, Robertson CS, Contant CF, Narayan RK Grossman RG. Continuous monitoring of jugular venous oxygen saturation in head injured patients. $\mathcal{F}$ Neurosurg 1992;72:212-7.

4 Chesnut RM, Marshall LF, Klauber MR, et al. The role of secondary brain injury in determining outcome from severe head injury. $f$ Trauma injury in determini

5 Pigula FA, Wald SL, Shackford SR, et al. The effect of hypotension and hypoxia on children with severe head injuries. $\mathcal{f}$ Pediatr Surg 1993;28:310-4.

6 Pickard JD, Czosnyka M. Management of raised intracranial pressure. $f$ Neurol Neurosurg Psychiatry 1993;66:845-58.

7 Kirkpatrick PJ, Czosnyka M, Pickard J. Multimodality monitoring in neurointensive care. $\mathcal{F}$ Neurol Neurosurg Psychiatry 1996;60:131-9. 